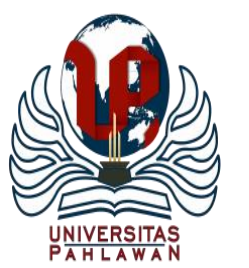

Jurnal Abdidas Volume 2 Nomor 5 Tahun 2021 Halaman 1204 - 1211

JURNAL ABDIDAS

http://abdidas.org/index.php/abdidas

\title{
Upaya Mewujudkan Sehat Jiwa dalam Penggunaan Gadget Selama Pandemi Covid-19 di SMA Hang Tuah Surabaya
}

\author{
Hidayatus Sya'diyah $^{1}$, Sukma Ayu Candra Kirana ${ }^{2 凶}$, Lela Nurlela $^{3}$, A.V. Sri Suhardiningsih ${ }^{4}$, Dya \\ Sustrami $^{5}$, Diyan Mutyah ${ }^{6}$ \\ Pendidikan Profesi Ners, STIKes Hang Tuah Surabaya, Indonesia ${ }^{1}$ \\ Keperawatan, STIKes Hang Tuah Surabaya, Indonesia ${ }^{2,3,4,5,6}$ \\ Email : hidayatussya'diyah@stikeshangtuah-sby.ac.id ${ }^{1}$, sukmaayucandrakirana@stikeshangtuah-sby.ac.id ${ }^{2}$, \\ lelanurlela@stikeshangtuah-sby.ac.id ${ }^{3,}$ aves@stikeshangtuah-sby.ac.id ${ }^{4}, \underline{\text { dyasustrami@ stikeshangtuah- }}$ \\ sby.ac.id $^{5}$, diyanmutyah@stikeshangtuah-sby.ac.id ${ }^{6}$
}

\begin{abstract}
Abstrak
Penerapkan Pemberlakuan Pembatasan Kegiatan Masyarakat (PPKM) untuk menekan penyebaran virus menyebabkan semua aktivitas dilakukan di rumah, salah satunya dibidang pendidikan yang memberlakukan pembelajaran jarak jauh (PJJ). Data menunjukkan $79 \%$ orang tua memberi izin ke anak memakai gadget untuk kegiatan selain belajar online dan hanya $21 \%$ orang tua yang melarang anak memakai gadget selain untuk belajar online, sehingga perlu diimbangi dengan kesehatan jiwa untuk mendukung kegiatan tersebut. Tujuan kegiatan ini adalah untuk meningkatkan peran siswa mewujudkan sehat jiwa bagi remaja dengan penggunaan gadget yang sering selama pandemi Covid-19 di SMA Hang Tuah Surabaya. Kegiatan melibatkan guru penanggung jawab UKS dan Guru BP, dan siswa. Kegiatan melalui tiga tahap yaitu tahap awal yaitu sosialisasi, tahap ke dua adalah pelaksanaan dan tahap ketiga evaluasi. Tahap pelaksanaan yang meliputi edukasi, pendampingan siswa dan diakhiri tahap evaluasi kegiatan. Edukasi mewujudkan sehat jiwa remaja di masa pandemi dilakukan melalui Google Meeting. Kegiatan dilaksanakan dengan baik dan diperoleh keadaan kesehatan jiwa siswa SMA Hang Tuah Surabaya mayoritas tidak mengalami gangguan mental emosional. Kepala sekolah beserta jajaran SMA Hang Tuah Surabaya mendukung keberlanjutan program pendampingan upaya pencegahan masalah kesehatan jiwa bagi siswanya.
\end{abstract}

Kata kunci: sehat jiwa, gadget, remaja

\section{Abstract}

The implementation of Community Activity Restrictions to suppress the spread of the Corona virus 19 causes all activities to be carried out at home, one of which is in the field of education that applies distance learning. Data showed that $79 \%$ of parents give permission to their children to use gadgets for activities other than online learning and only $21 \%$ of parents prohibit their children from using gadgets other than online learning, so it needs to be balanced with mental health to support these activities. The purpose of this activity was to increase the role of students in realizing mental health for teenagers by using gadgets frequently during the Covid-19 pandemic at Hang Tuah High School Surabaya. The activity involved the UKS teacher in charge and the BP teacher, and students. The activity goes through three stages, that was the primary stage including socialization, the second stage was implementation and the third stage was evaluation. The implementation stage which included education, student assistance and ends with the activity evaluation stage. Education for realizing healthy adolescent mentality during the pandemic was carried out through Google Meetings. The activity was carried out well and the mental health condition of the Hang Tuah High School Surabaya students did not experience mental-emotional disorders. The principal and the staff of Hang Tuah High School Surabaya support the sustainability of the mentoring program to prevent mental health problems for their students.

Keywords: mental health, gadgets, teenagers

Copyright (c) 2021 Hidayatus Sya'diyah, Sukma Ayu Candra Kirana, Lela Nurlela, A.V. Sri Suhardiningsih, Dya Sustrami' Diyan Mutyah

$\triangle$ Corresponding author

Address : STIKES Hang Tuah Surabaya

Email : hidayatussya'diyah@stikeshangtuah-sby.ac.id

DOI : https://doi.org/10.31004/abdidas.v2i5.397

ISSN 2721-9224 (Media Cetak)

ISSN 2721- 9216 (Media Online) 
1205 Upaya Mewujudkan Sehat Jiwa Dalam Penggunaan Gadget Selama Pandemi Covid-19 Di Sma Hang Tuah Surabaya - Hidayatus Sya'diyah, Sukma Ayu Candra Kirana, Lela Nurlela, A.V. Sri Suhardiningsih, Dya Sustrami, Diyan Mutyah DOI: https://doi.org/10.31004/abdidas.v2i5.397

\section{PENDAHULUAN}

Covid-19 adalah penyakit yang disebabkan oleh virus SARS-CoV2. Virus ini dapat menyebar melalui droplet. Penyebarannya yang cepat membuat beberapa negara menerapkan kebijakan lockdown. Di Indonesia, pemerintah menerapkan Pemberlakuan Pembatasan Kegiatan Masyarakat (PPKM) untuk menekan penyebaran virus ini. Semua aktivitas dilakukan di rumah, salah satunya dibidang pendidikan yang memberlakukan pembelajaran jarak jauh (PJJ). Teknis pembelajaran jarak jauh ini menggunakan gadget untuk mengikuti pembelajaran sepanjang hari. Gadget merupakan salah satu bagian dari perkembangan teknologi yang selalu menghadirkan teknologi terbaru yang dapat membantu berbagai kegiatan manusia menjadi lebih mudah. Gadget di anggap lebih lengkap dari pada alat elektronik lainnya karena fungsi dan sifatnya yang berbeda. Kehadiran gadget di zaman yang serba canggih dan masa pandemi ini sudah menjadi kebutuhan utama bagi para pelajar untuk keperluan pendidikan guna menunjang proses pembelajaran (Kemendikbud, 2019).

Survei Komisi Perlindungan Anak Indonesia yang dilakukan pada tanggal 8-14 Juni 2020 terhadap 25.164 responden anak dan 14.169 responden orang tua yang tersebar di 34 provinsi melalui kuesioner online. Hasil survei menunjukkan sebanyak $79 \%$ orang tua memberi izin ke anak memakai gadget untuk kegiatan selain belajar online dan hanya $21 \%$ orang tua yang melarang anak memakai gadget selain untuk belajar online. Selain itu $88,2 \%$ gadget masih berada di bawah kepemilikan penuh orang tua dan 11,6 persen menunjukkan kepemilikan bersama gadget antara orang tua dan anak. Sedangkan alasan pemakaian gadget sebagai sarana mencari pengetahuan $74,1 \%$, sarana informasi $71,4 \%$, bisa membuat tulisan video dan aktivitas produktif lainnya 44,9\% (Azizah, 2020).

Penggunaan ponsel secara berlebihan dapat meningkatkan risiko untuk terjadi berbagai dampak baik negatif maupun positif. Manfaat positif penggunaan gadget di lingkungan sekolah yaitu (1) Mempermudah kegiatan belajar mengajar; (2) Menambah wawasan tentang perkembangan teknologi dan informasi; (3) Mempermudah interaksi peserta didik dengan guru, misalnya peserta didik bertanya tentang pelajaran yang kurang mengerti ketika belajar dalam kelas; (4) Bisa digunakan dalam belajar sambil mendengarkan musik sehingga siswa bisa lebih rileks. Dampak negatif penggunaan gadget yaitu: (1) Mengganggu perkembangan anak. Dengan modernnya perangkat yang adadi gadget seperti kamera, permainan akan mempengaruhi konsentari peserta didik dalam belajar di sekolah; (2) Menjadi budak teknologi; (3) Prestasi akademik menurun; (4) Dapat menyebabkan kecanduan; (5) Sangat mempengaruhi karakter siswa; (6) Menciptakan lingkungan pergaulan sosial yang tidak sehat; (7) Cenderung individualis, susah bergaul, sulit dikontrol dan sulit berkembang, malas beraktifitas, menjadi sebuah kebiasaan, sulit fokus dalam belajar, anti sosial dengan lingkungan sekitar; (9) Radiasi yang dikeluarkan gadget merupakan penyebab kanker 
1206 Upaya Mewujudkan Sehat Jiwa Dalam Penggunaan Gadget Selama Pandemi Covid-19 Di Sma Hang Tuah Surabaya - Hidayatus Sya'diyah, Sukma Ayu Candra Kirana, Lela Nurlela, A.V. Sri Suhardiningsih, Dya Sustrami, Diyan Mutyah

DOI: https://doi.org/10.31004/abdidas.v2i5.397

seperti tiroid, leukemia, payudara, kanker perut, gangguan tidur, gangguan penglihatan (rabub dekat) gangguan pendengaran; (10) Tugas pelajar yang melebihi batas normal akan berdampak pada kesehatan mata, stress, mudah marah, persoalan mental dan bunuh diri (Ariston, 2018).

Oleh karena itu salah satu upaya yang dapat dilakukan guru terhadap sisi negatif yang ditimbulkan gadget adalah profesionalisme di dalam pembelajaran, adanya larangan menggunakan gadget saat terjadinya kegiatan belajar mengajar di kelas, serta bantuan pengawasan orang tua. Tidak kalah penting kesadaran dari setiap siswa akan manfaat penggunaan gadget dan efek penggunaan gadget yang dapat menunjang prestasi belajar siswa. Peran orang tua sangat berpengaruh terhadap psikologi perkembangan anak akan adanya bimbingan, arahan, pengawasan dan juga dukungan penuh agar anak merasa percaya diri terhadap kemampuan yang dimilikinya. Orang tua dan guru memang harus mencari solusi agar gadget tidak berdampak buruk pada anak didik (Anwar, 2021).

Berdasarkan latar belakang tersebut, departemen jiwa dan gerontik STIKES Hang Tuah Surabaya melakukan pengabdian masyarakat kepada siswa SMA Hang Tuah Surabaya tentang Upaya Mewujudkan Sehat Jiwa dalam Penggunaan Gadget Selama Pandemi Covid-19.

\section{METODE}

Kegiatan pengabdian masyarakat upaya mewujudkan sehat jiwa dalam penggunaan gadget masa pandemi pada siswa dalam hal ini siswa SMA Hang Tuah Surabaya dilakukan pada Bulan Juni 2021 selama 1 minggu dengan jumlah peserta yang diharapkan 100 peserta. Namun yang hadir secara online hanya 152 siswa. Media yang digunakan adalah Google Meet untuk tatap muka secara virtual. Selain itu materi, link absen, link evaluasi telah dipersiapkan untuk menunjang selama kegiatan pengabdian masyarakat secara online berlangsung.

\section{Tahap Pertama}

Tahap pertama merupakan sosialisasi kepada Kepala Sekolah, guru kesiswaan dan guru UKS tentang apa, dampak, dan bagaimana pelaksanaan "Upaya Mewujudkan Sehat Jiwa dalam Penggunaan Gadget Selama Pandemi Covid-19”. Sosialisasi tersebut bertujuan untuk mengenalkan apa saja tindakan yang akan kita lakukan selama pengabdian masyarakat berlangsung. Mulai dari koordinasi ijin, penyampaian mekanisme kegiatan, penentuan jadwal pelaksanaan dan evaluasi.

\section{Tahap Kedua}

Tahap kedua merupakan tahap pelaksanaan yang terdiri dari edukasi, pelatihan dan pendampingan siswa. Edukasi dilaksanakan secara virtual menggunakan google meet dengan materi Sehat Jiwa dalam penggunaan gadget selama pandemi Covid-19. Materi tersebut dibawakan secara langsung oleh tim keperawatan jiwa dan gerontik. Tahap selanjutnya adalah pelatihan relaksasi yang dilakukan secara Bersama sama dengan membentuk kelompok kelompok siswa yang terdiri dari 7-8 siswa untuk belajar tahapan relaksasi nafas dalam 
1207 Upaya Mewujudkan Sehat Jiwa Dalam Penggunaan Gadget Selama Pandemi Covid-19 Di Sma Hang Tuah Surabaya - Hidayatus Sya'diyah, Sukma Ayu Candra Kirana, Lela Nurlela, A.V. Sri Suhardiningsih, Dya Sustrami, Diyan Mutyah

DOI: https://doi.org/10.31004/abdidas.v2i5.397

dengan baik. Siswa diberikan materi terlebih dahulu untuk dapat berdiskusi pada saat tatap muka online.

3. Tahap Ketiga

Tahap ketiga adalah monitoring dan evaluasi kegiatan. Proses ini juga dilakukan oleh tim pengabdian masyarakat dan siswa untuk mengetahui apakah upaya mewujudkan sehat jiwa tersebut dpat diterapkan dengan mudah oleh guru dan siswa. Monitoring evaluasi yang dilakukan adalah melakukan menyebaran kuesioner melalui link evaluasi setelah pelaksanaan tahap kedua pengabdian masyarakat. Hasil tersebut di tabulasi setelah tahap ketiga dilaksanakan serta dijabarkan di hasul dan pembahasan.

\section{HASIL DAN PEMBAHASAN}

Kegiatan pengabdian masyarakat ini merupakan bentuk upaya mewujudkan sehat jiwa dalam penggunaan gadget selama masa pandemi yang berfokus pada perubahan perilaku masyarakat dalam hal ini adalah kelompok khusus remaja yang berstatus sebagai siswa SMA Hang Tuah Surabaya. Upaya merubah perilaku siswa melalui pemberdayaan masyarakat ini melibatkan penggerak kesehatan Guru penanggung jawab UKS dan Kepala Sekolah beserta staf dengan melakukan sosialisasi terhadap siswa tentang pentingnya menjaga Kesehatan Jiwa selama pamdemi Covid-19. Melalui tahap sosialisasi segala kebutuhan SMA akan masalah kesehatan jiwa siswa dapat diwadahi, sehingga dapat direncanakan kegiatan edukasi, pelatihan sebagai upaya penyelesaian masalah.
Kegiatan edukasi berjalan dengan baik dan siswa antusias dengan materi yang telah disampaikan. Edukasi yang telah disampaikan merupakan informasi tentang sehat jiwa yang seharusnya pada remaja selama pandemi covid-19, bagaimana cara mewujudkannya, apa manfaat positif dan dampak negative dalam penggunaan gadget di masa pandemi. Edukasi merupakan hal yang sangat penting diberikan untuk dapat meningkatkan pemahaman siswa tentang Kesehatan Jiwa dalam penggunaan gadget selama Pandemi Covid-19, sehingga akan sangat membantu dalam pencegahan terjadinya masalah kesehatan jiwa.

Tabel 1 menunjukkan uang saku siswa perhari rata-rata Rp. 5.000-10.000, dengan pekerjaan ayah rata-rata wiraswasta, pekerjaan ibu rata-rata sebagai ibu rumah tangga, serta Pendidikan orang tua rata-rata SMA. Sedangkan tabel 2 menunjukkan mayoritas tingkat kecanduan gadget pada siswa SMA di Surabaya berada pada tingkat sedang dengan prosentase $71,43 \%$. Siswa SMA lainnya mengalami kecanduan gadget Rendah sebanyak 15,08\% sedangkan lainnya mengalami gangguan berat $(13,49 \%)$. 
1208 Upaya Mewujudkan Sehat Jiwa Dalam Penggunaan Gadget Selama Pandemi Covid-19 Di Sma Hang Tuah Surabaya - Hidayatus Sya'diyah, Sukma Ayu Candra Kirana, Lela Nurlela, A.V. Sri Suhardiningsih, Dya Sustrami, Diyan Mutyah

DOI: https://doi.org/10.31004/abdidas.v2i5.397

Tabel 1. Identifikasi Responden Siswa SMA Hang Tuah Surabaya

\begin{tabular}{|c|c|c|c|c|c|c|c|c|c|c|c|}
\hline \multicolumn{3}{|c|}{ Uang saku perhari } & \multicolumn{3}{|c|}{ Pekerjaan Ayah } & \multicolumn{3}{|c|}{ Pekerjaan Ibu } & \multicolumn{3}{|c|}{ Pendidikan Orang Tua } \\
\hline Kriteria & $\mathrm{f}$ & $\%$ & Kriteria & $\mathrm{f}$ & $\%$ & Kriteria & $\mathrm{f}$ & $\%$ & Kriteria & $\mathrm{f}$ & $\%$ \\
\hline$<$ Rp.5000 & 15 & 5.95 & Petani & 19 & 7.54 & $\begin{array}{c}\text { Ibu Rumah } \\
\text { Tangga }\end{array}$ & 150 & 59.52 & SD & 72 & 28.57 \\
\hline $\begin{array}{l}\text { Rp.5.000- } \\
\text { Rp10.000 }\end{array}$ & 155 & 61.51 & Guru & 10 & 3.97 & Petani & 5 & 1.98 & SMP & 43 & 17.06 \\
\hline $\begin{array}{l}\text { Rp.11.000- } \\
\text { Rp.20.000 }\end{array}$ & 73 & 28.97 & Tni/Polri & 14 & 5.56 & Pns/Asn/Guru & 17 & 6.75 & SMA & 109 & 43.25 \\
\hline $\begin{array}{l}\text { Rp.21.000- } \\
\text { Rp.30.000 }\end{array}$ & 8 & 3.17 & Swasta & 94 & 37.3 & Swasta & 30 & 11.9 & D3 & 3 & 1.19 \\
\hline$>$ Rp. 31.000 & 1 & 0.40 & Wiraswasta & 115 & 45.63 & Wiraswasta & 50 & 19.84 & $\mathrm{D} 4 / \mathrm{S} 1$ & 23 & 9.13 \\
\hline TOTAL & 252 & 100 & & 252 & 100 & & 252 & 100 & & 252 & 100 \\
\hline
\end{tabular}

Tabel 2. Identifikasi Kecanduan Gadget

\begin{tabular}{clcc}
\hline No & Kriteria & F & \% \\
\hline 1 & Tinggi & 38 & 13,49 \\
\hline 2 & Sedang & 180 & 71,43 \\
\hline 3 & rendah & 34 & 15,08 \\
\hline & Total & 252 & 100 \\
\hline
\end{tabular}

Tabel 3. Identifikasi Gangguan Mental Emosional Pada Siswa SMA

\begin{tabular}{lllccc}
\hline No & Kriteria & \multicolumn{2}{c}{ pretest } & \multicolumn{2}{c}{ posttest } \\
\cline { 3 - 6 } frekuensi & & $\begin{array}{c}\text { persentase } \\
(\mathbf{\%})\end{array}$ & $\begin{array}{c}\text { frekuensi } \\
(\mathbf{f})\end{array}$ & $\begin{array}{c}\text { persentase } \\
(\boldsymbol{\%})\end{array}$ \\
\hline 1 & $\begin{array}{l}\text { Tidak ada } \\
\text { gangguan } \\
\text { mental } \\
\text { emosional }\end{array}$ & 194 & 76,9 & 214 & 84,9 \\
\hline 2 & $\begin{array}{l}\text { Gangguan } \\
\text { mental } \\
\text { emosional }\end{array}$ & 58 & 23,1 & 38 & 15,1 \\
\hline & & & & \\
\hline & & & & \\
\hline
\end{tabular}

Pada Tabel 3 dijelaskan bahwa terdapat gangguan mental emosional sebelum dilakukan edukasi. Pengukuran dengan menggunakan SRQ-29 (self report quesionare) sebanyak 29 pertanyaan. Terdapat beberapa gejala pada masalah emosilonal mulai dari gejala neurosis, gejala psikotik, gejala Psicosocial T Syndome Desease serta penyalahgunaan zat adiktif. Gejala neurosis yang dinilai dalam SRQ-29 hampir sama dengan gejala depresi yang meliputi gejala somatik, perasaan tidak bahagia, cemas, ketakutan dan kurang percaya diri. Sedangkan setelah dilakukan edukasi, siswa yang mengalami gangguan mental emosional mengalami penurunan dan yang tidak mengalami gangguan mental emosional mengalami peningkatan.

Gadget yang dipergunakan oleh siswa antara lain: 1) Laptop, komputer jinjing yang bisa dibawa kemana saja berukuran relatif kecil dan ringan. Beratnya berkisar dari 1- $6 \mathrm{~kg}$, tergantung ukuran, bahan, dan spesifikasi laptop tersebut. Manfaat dari laptop adalah membantu menyelesaikan pekerjaan lebih cepat, menambah maya kreatifitas otak dan fleksibel; 2) Smartphone, perangkat telekomunikasi serba guna, atau yang juga disebut piranti pintar yang menjadi trend yang mewabah, fitur yang ditawarkan sangat menarik dan mengubah hobi pengguna untuk browsing, chatting dan lain lain. Manfaat dari smartphone antara lain : memudahkan pengguna dalam berkomunikasi, mencari ilmu yang lebih luas, serta mempermudah penggunaannya dalam melakukan hubungan sosial (Jamaiah, 2021) (Jamaiah, 2021).

Gadget mempunyai manfaat yang cukup banyak dalam penggunaanya antara lain: 1) Memperlancar komunikasi, mempermudah komunikasi dengan seseorang yang tidak berada didekatnya sehingga tidak membutuhkan waktu 
1209 Upaya Mewujudkan Sehat Jiwa Dalam Penggunaan Gadget Selama Pandemi Covid-19 Di Sma Hang Tuah Surabaya - Hidayatus Sya'diyah, Sukma Ayu Candra Kirana, Lela Nurlela, A.V. Sri Suhardiningsih, Dya Sustrami, Diyan Mutyah

DOI: https://doi.org/10.31004/abdidas.v2i5.397

yang lama yang untuk menyampaikan pesan sehingga memperbanyak teman; 2) Mengakses informasi, informasi sesuai kebutuhan sehingga mempermudah untuk melakukan suatu aktivitas; 3) Mempermudah memperkenalkan budaya dalam negeri dan luar negeri; 4) Hiburan, terdapat aplikasi permainan, pemutar musik, kamera dan lain-lain. Selain itu terdapat dampak negatif yang dapat diterima dari penggunaan gadget 1) Segi Kesehatan, penggunaan secara berlebih dapat meningkatkan risiko kanker, karena tingginya radiasi yang diberikan oleh perangkat tersebut. Radiasi komputer dapat mengakibatkan rabun mata, katarak,epilepsi. Akan tetapi efeknya baru dirasakan 15 atau 20 tahun kemudian. Penggunanaan cahaya atau pencerahan maksimal secara kontinyu pada ponsel, komputer, tablet dan lain-lain bisa mengakibatkan perih pada mata dan lebih parahnya bisa menimbulkan rabun dekat; 2) Segi budaya, menjadi faktor lunturnya suatu adat kebiasaan yang ada di masyarakat, sebab gadget dapat mempengaruhi pandangan penggunanya tentang kebiasaan adat istiadat yang dinilai masih radisional dan tidak mengikuti perkembangan zaman. Masuknya budaya barat secara perlahan dapat menggeser keberadaan adat di masyarakat karena banyaknya web yang memposting kebudayaan asing tanpa ada filterisasi yang baik; 3) Segi sosial, kecanggihan gadget dapat mengurangi jiwa sosial para penggunanya, sebab mereka cenderung bergantung pada kecanggihan teknologi. Cepat bosan ketika ada orang yang menasehati. Banyak mengeluh ketika sebanyak masalah. Emosi tidak terkendali. Kemudahan akses internet sehingga seseorang dapat dengan mudah membuka informasi yang tidak baik; 4) Segi ekonomi, membutuhkan pengeluaran lebih untuk memenuhi kebutuhan gadget (Ariston, 2018).

Beberapa rekomendasi untuk mengurangi dampak kecanduan gadget dan mewujudkan kesehatan jiwa yang optimal.

1. Batasi waktu

Menurut sebuah penelitian di Chinese Academy of Science, ternyata kecanduan gadget dan internet mampu merubah susunan otak seseorang. Hal ini sama seperti yang terjadi pada orang yang kecanduan rokok dan narkoba. Sesekali bersosialisasilah dan pahami bahwa kamu masih punya lingkungan sosial yang butuh perananamu, di samping itu melihat layar yang sehat untuk anak berusia 2-4 tahun yaitu di bawah 1 jam per hari. Sementara untuk anak yang lebih dewasa dari itu biasanya tidak lebih dari tiga jam.

2. Tidak menggunakan gadget sebelum tidur Tidur merupakan salah satu kebutuhan pokok sebagai mahluk hidup. Oleh karena itu, jauhkan gadgetmu kurang lebih 1 jam sebelum tidur. Hasil penelitian mengungkapkan bahwa seseorang akan mengalami sulit tidur dan insomnia jika sebelum tidur ia mengoperasikan gadget terlebih dahulu.

3. Jangan Terlalu Menunduk Saat Mengoperasikan Gadget

Cara ini juga menjadi sesuatu yang penting agar kamu tetap sehat dan tak mengalami dampak negatif smartphone. Usahakan untuk melihat 
1210 Upaya Mewujudkan Sehat Jiwa Dalam Penggunaan Gadget Selama Pandemi Covid-19 Di Sma Hang Tuah Surabaya - Hidayatus Sya'diyah, Sukma Ayu Candra Kirana, Lela Nurlela, A.V. Sri Suhardiningsih, Dya Sustrami, Diyan Mutyah

DOI: https://doi.org/10.31004/abdidas.v2i5.397

gadget dalam kondisi sejajar dengan mata dan jangan terlalu menunduk.

4. Usahakan keseimbangan aktivitas

Sebisa mungkin dorong anak agar tetap aktif secara fisik, tidak hanya menghabiskan waktu dengan gawai. Ciptakan suasana yang nyaman di rumah sehingga anak terdorong untuk melakukan aktivitas fisik.

5. Berikan aturan yang jelas

"Buat aturan yang jelas mengenai penggunaan gadget/internet : Kapan, di mana, bagaimana. Aturan ini harus diterapkan secara tegas dan diikuti oleh semua anggota keluarga.

6. Pantau akses

Pantau akses penggunaan gawai dengan menggunakan perangkat bersama. Ambil kesempatan bebas gawai untuk berkomunikasi, berinteraksi dan berbagi nilai-nilai keluarga bersama anak.

7. Beri pujian

Pastikan untuk memberikan pujian pada anak ketika mereka tidak menggunakan ponsel. Baik apakah itu karena keputusan sendiri atau karena telah mengikuti aturan yang telah ditetapkan.

Adapun tips belajar sehat dengan gadget saat pandemi (Anwar, 2021).:

1. Tanamkan motivasi yang kuat

2. Mengkondisikan tempat belajar yang nyaman

3. Membuat jadwal harian

4. Jangan malu bertanya
5. Tetap menjaga kesehatatan selaa belajar : posisi duduk, minum air putih , peregangan dll

Kegiatan pengabdian masyarakat ini merupakan kegiatan wajib dalam melaksanakan tri dharma perguruan tinggi yang dilakukan STIKES Hang Tuah Surabaya bekerjasama dengan SMA Hang Tuah Surabaya. Melalui pengabdian ini dan dilakukan edukasi, status kesehatan jiwa remaja di Surabaya dengan indikator yang mengalami gangguan mental emosional mengalami penurunan dari sebelum dilakukan edukasi dibandingkan setelah dilakukan edukasi. Sedangkan siswa yang tidak mengalami gangguan mental emosional mengalami peningkatan dari yang sebelum dilakukan edukasi dibandingkan dengan setelah dilakukan edukasi.

Dampak dan manfaat kegiatan pengabdian masyarakat ini adalah cukup besar bagi siswa remaja pada khususnya dan masyarakat pada umumnya, diingat bahwa penggunaan gadget bagi siswa remaja dalam kategori sedang hingga tinggi khususnya dalam melakukan pembelajaran di era pandemi. Penggunan gadget oleh siswa remaja tidak hanya untuk pendidikan saja, namun dengan alasan untuk mengisi waktu luang saat bosan dengan pembelajaran daring, siswa remaja biasanya menggunakan gadget untuk bermain game, atau melakukan aplikasi lainnya secara online. Dengan demikian, edukasi sangat bermanfaat bagi masyarakat untuk menurunkan gejala mental emosional khususnya yang mengalami gangguan gadget. 
1211 Upaya Mewujudkan Sehat Jiwa Dalam Penggunaan Gadget Selama Pandemi Covid-19 Di Sma Hang Tuah Surabaya - Hidayatus Sya'diyah, Sukma Ayu Candra Kirana, Lela Nurlela, A.V. Sri Suhardiningsih, Dya Sustrami, Diyan Mutyah

DOI: https://doi.org/10.31004/abdidas.v2i5.397

\section{SIMPULAN}

Kegiatan pengabdian masyarakat dengan upaya mewujudkan sehat jiwa dalam penggunaan gadget selama masa pandemic Covid-19 yang berfokus pada pencegahan masalah kesehatan jiwa remaja telah dilaksanakan. Kegiatan ini diterima oleh SMA Hang Tuah Surabaya dengan baik dan antusias. Tim pengabdian, Kepala sekolah, guru dan siswa saling membantu melaksanakan edukasi dalam sebagai salah satu upaya mengatasi masalah kesehatan jiwa. Evaluasi yang didapatkan tidak terdapat siswa yang mengalami gangguan mental emosional.

Sekolah sebaiknya bekerjasama dengan institusi pendidikan untuk mendapatkan pendidikan kesehatan dalam kesehatan fisik maupun mental untuk menjaga status kesehatan peserta didiknya. Apalagi dalam kondisi pandemi Covid-19 yang rentan sekali mengalami masalah kesehatan baik fisik maupun mental.

\section{UCAPAN TERIMAKASIH}

1. Kepala Sekolah SMA Hang Tuah Surabaya beserta Guru dan Staf yang telah memberikan arahan dan memfasilitasi kegiatan pengabdian masyarakat ini.

2. Siswa Siswa SMA Hang Tuah Surabaya yang telah berpartisipasi dalam kegiatan ini.

3. Dosen dan Staf STIKES Hang Tuah Surabaya yang telah berpartisipasi dalam kegiatan.
Ariston, Y. Dan F. 2018 (2018) .'Dampak Penggunaan Gadget Bagi Perkembangan Sosial Anak Sekolah. Journal Of Educational Review And Research. Volume 1. No. 2 Santrock, John W. 2012. " Life-Span Development Perkembangan Masa-Hidup "', Jakarta: Erlangga.

Azizah (2020) 'Survei KPAI: 79\% Anak Pakai Gadget Selain Untuk Belajar Selama Pandemi Corona', Kumparan News.

Jamaiah (2021) 'Pengaruh Gadget Pada Siswa Di Masa Pandemi.', Naikpangkat.Com, All Rights Reserved.

Kemendikbud (2019) 'No 1. Anwar. 2021. 5 Tips Agar Anak Tak Kecanduan Gadget Di Masa Pandemi. Detikhealth 2. Ariston, Yummi Dan Frahasini. 2018. Dampak Penggunaan Gadget Bagi Perkembangan Sosial Anak Sekolah. Journal Of Educational Review And Research. Volume 1. No. 2 Santro', In. Kemendikbud.

\section{DAFTAR PUSTAKA}

Anwar (2021) '5 Tips Agar Anak Tak Kecanduan Gadget Di Masa Pandemi.', Detikhealth. 